\title{
PENGARUH LOKASI BANK RAKYAT INDONESIA KANTOR CABANG PEMBANTU UNIT INOBONTO TERHADAP MINAT NASABAH UNTUK MENABUNG
}

\author{
Olive Mariana Paputungan \\ Fakultas Ekonomi dan Bisnis Islam, Institut Agama Islam Negeri Manado \\ E-mail: Olvipaputungan@iain-manado.ac.id \\ Syarifuddin \\ Fakultas Ekonomi dan Bisnis Islam, Institut Agama Islam Negeri Manado \\ E-mail: Syarifuddin@iain-manado.ac.id

\section{Ramli Semmawi} \\ Fakultas Ekonomi dan Bisnis Islam, Institut Agama Islam Negeri Manado \\ E-mail: ramlisemmawi@iain-manado.ac.id
}

\begin{abstract}
ABSTRAK
Penelitian ini bertujuan untuk mengetahui Pengaruh Lokasi Bank BRI Kantor Cabang Pembantu Unit Inobonto Terhadap Minat Menabung nasabah Desa Bantik. Dan menggunakan penelitian kuantitatif, Populasi dalam penelitian adalah Nasabah Bank BRI Desa Bantik. Teknik pengambilan sampel yang di ambil dalam peneitian ini menggunakan rumus Hair sehingga di dapatkan sampel sebanyak 110 responden. Data yang digunakan dalam penelitian ini adalah data primer. Teknik analisis data yang digunakan dalam penelitian ini yaitu uji validitas, uji reliabilitas, uji normalitas, uji korelasi, uji regresi linier sederhana, dan uji t (persial). Hasil dalam penelitian mengungkapkan bahwa Lokasi Bank BRI Kcp Unit Inobonto berpengaruh terhadap minat nasabah di Desa Bantik untuk menabung di Bank BRI Kcp Unit Inobonto. Hal ini menunjukkan bahwa nilai thitung 8,167> ttabel 1,982 sehingga Ha diterima dan Ho ditolak. Selain itu, berdasarkan nilai signifikasi dari tabel Cofficients diperoleh nilai signifikasi sebesar $0,000<0,05$ maka Ho ditolak dan Ha diterima. Sehingga dapat disimpulkan bahwa Lokasi Bank BRI Kcp Unit Inobonto berpengaruh terhadap Minat Menabung Nasabah di Desa Bantik.
\end{abstract}

Kata kunci: Bank; Lokasi; Minat Menabung; Nasabah; Pengaruh. 


\section{PENDAHULUAN}

Zaman modern saat ini, peranan perbankan dalam memajukan sesuatu negara sangatlah besar, nyaris seluruh zona yang berhubungan dengan bermacam aktivitas keuangan senantiasa memerlukan jasa perbankan (Kasmir, 2004). Peran perbankan dalam perekonomian selaku intermediary institution dalam menghimpun dan menyalurkan dana masyarakat bagi pembiayaan kegiatan sektor perekonomian sehingga akan memperkuat struktur perekonomian suatu negara (Simatupang, 2019). Perbankan sangat memengaruhi aktivitas ekonomi sesuatu negara, bank bisa dikatakan sebagai darah perekonomian sesuatu negara. Oleh sebab itu, kemajuan sesuatu bank disuatu negara bisa pula dijadikan dimensi kemajuan negara yang bersangkutan. Perkembangan perbankan menunjukkan dinamika ekonomi (Pandiangan, 2018). Perbankan memiliki andil dalam kemajuan ekonomi suatu negara, jadi keberadaan dunia perbankan sangat dibutuhkan pemerintah serta masyarakatnya.

Bank adalah lembaga keuangan ataupun industri yang bergerak di bidang keuangan (Wiwoho, 2014). Bank menurut UU nomor 10 tahun 1998 tentang perbankan merupakan lembaga usaha yang menghimpun dana dari rakyat dalam wujud simpanan serta menyalurkan kepada rakyat dalam wujud kredit serta bentuk-bentuk yang lain dalam tingkatkan taraf hidup rakyat banyak. Dari pemahaman UU No 10 Tahun 1998 bisa disimpulkan jika dalam perbankan aktivitas menghimpun dana dan menyalurkan dana adalah aktivitas pokok bank sebaliknya membagikan jasa bank yang lain hanya aktivitas pendukung.

Menurut Kasmir (2017) Bank selaku lembaga keuangan yang memberikan jasa keuangan memerlukan strategi pemasaran agar dapat memasarkan produknya. Secara universal tujuan pemasaran bank ialah untuk:

1. Memaksimumkan mengkonsumsi ataupun dengan kata lain mempermudah serta memicu konsumsi, sehingga bisa menarik nasabah supaya membeli produk yang ditawarkan bank secara berulang-ulang.

2. Memaksimumkan kepuasan konsumen lewat pelayanan yang di harapkan nasabah. Dengan menyediakan opsi (ragam produk) sehingga nasabah juga mempunyai bermacam-macam pilihan.

3. Memaksimumkan kualitas hidup dengan membagikan bermacam kemudahan kepada nasabah serta menghasilkan situasi yang efektif

Melihat tujuan pemasaran bank ataupun lembaga keuangan sekarang ini, sepatutnyalah pihak lembaga keuangan tersebut bisa mempraktikkan strategi supaya nasabah termotivasi buat menabung, ialah dengan memenuhi kebutuhan serta kemauan nasabah. Dengan kata lain, lembaga keuangan tersebut wajib meningkatkan mutu pelayanan, tidak hanya mutu pelayanan yang wajib ditingkatkan, pemilihan lokasi juga merupakan strategis yang sangat mendukung keberlangsungan suatu industri, termasuk industri perbankan. Mutu layanan tidak terbatas pada tingkat pemahaman perusahaan tentang harapan dan kenyataan atau kinerja nyata yang dirasakan pelanggan. Hadiwijaya (2020) menjelaskan bahwa mutu layanan sebagai alat perusahaan bertujuan 
Kunuz: Journal of Islamic Banking and Finance Vol. 1, No. 1 (2021): 10-21 Website: http://ejournal.iain-manado.ac.id/index.php/kunuz

mempengaruhi dan kemudian mengendalikan pelanggan untuk bekerja secara sadar demi kepentingan perusahaan.

Menabung ialah aktivitas ataupun kegiatan yang membuat timbulnya kemauan dalam diri seorang buat menyisikan serta menaruh uangnya di bank (Reshita, 2015). Reshita menjelaskan bahwa butuh minat supaya perilakunya terencana pada kegiatan tersebut (menabung). Dalam upaya menarik minat nasabah buat menabung di bank dilaksanakan bermacam strategi industri antara lain: promosi, lokasi, serta kualitas pelayanan (Astuti \& Mustikawati, 2013). Minat menabung merupakan kekuatan yang memotivasi seseorang agar membagikan perhatiannya terhadap aktivitas menaruh uang di bank yang dilaksnakan secara sadar tidak terpaksa serta dalam perasaan bahagia. Minat menabung nasabah juga sangat mempengaruhi terhadap kelangsungan hidup pada dunia perbankan. Tanpa terdapatnya minat menabung masyarakat, maka perekonomian di Indonesia hendak terpuruk sebab tidak terjadi perputaran uang yang menunjang roda perekonomian bangsa (Hasibuan, 2020).

Ada banyak aspek yang wajib dicermati, salah satunya adalah bank mencermati lokasi yang digunakan dalam melaksanakan usahanya (Daroin \& Ningtias, 2020). Penentuan lokasi bank adalah sesuatu kebijakan yang wajib diambil dengan hati-hati. Lokasi butuh dipilih sebab salah satu faktor yang menjadi keberhasilan usaha sangat bergantung pada pemilihan lokasi yang tepat.

Dalam pemilihan lokasi untuk mendukung operasional industri, bagian strategi yang harus diperhatikan, antara lain akses lokasi usaha haruslah strategis hingga dapat dijangkau dengan muda untuk konsumen. Aksebilitas memiliki makna ekonomi, dan berkaitan dengan daya jangkau atau keterjangkauan suatu lokasi, sehingga memengaruhi biaya (Baja, 2012). Artinya dapat dijangkau baik pejalan kaki maupun ketersediaan transportasi umum. Lokasi menjadi salah satu aspek yang berpengaruh terhadap nasabah disebakan oleh keterjangkauan antara rumah nasabah dengan lokasi bank serta lokasi yang gampang dijangkau oleh kendaraan dan keadaan gedung dengan terdapatnya pengaturan ruang.

Terdapat beberapa artikel dan kajian terkait pengaruh lokasi terhadap minat nasabah untuk menabung. Penelitian (Homsatun, 2017) menyatakan bahwa lokasi, Pelayanan dan kualitas produk terhadap minat nasabah untuk menabung pada PT Bank Muamalat Tbk. Cabang Kendari berpengaruh positif. Sedangkan penelitian yang dilaksnakan oleh Karina Halima Asmar (2019) yang berjudul "Pengaruh Pelayanan, Promosi, Lokasi dan Bagi Hasil Bank Terhadap Minat Nasabah Menabung Pada PT Bank Bri Syariah Kcp Sudirman Lubuk pakan" menyatakan bahwa variabel pelayanan mempunyai pengaruh positif untuk variabel minat nasabah untuk menabung, kemudian analisis secara persial variabel lokasi mempunyai pengaruh negatif terhadpa variabel minat menabung. Terdapat perbedaan-perbedaan dengan penelitian ini terdapat pada uji persial untuk lokasi, di mana pada penelitian Homsatun lokasi tidak pengaruhi untuk minat nasabah menabung, sedangkan dalam penelitian penulis lokasi berpengaruh untuk minat nasabah menabung di bank. Perbedaan lainnya dengan penelitian penulis ini terdapat pada objek penelitian, dimana penelitian yang dilakukan Homsatun objek penelitiannya di Bank. Adapun penelitian saat ini berfokus pada masyarakat di Desa 
Bantik dengan responden sebanyak 110 orang. Perbedaan lainnya juga pada variabel penelitian dimana Homsatun meneliti lokasi, pelayanan dan kualitas, penelitian ini berfokus pada lokas.

Lingkungan yang menjadi dasar penelitian ini memiliki 3 bank yang berdekatan, di antaranya Bank Sulut Go, Bank Bri dan Bank Mandiri, kemudian dalam penelitian ini peneliti tertarik dan memilih lokasi Bank Bri. Salah satu kunci sukses suatu industry adalah lokasi industry tersebut (Kotler \& Keller, 2011). Lokasi Bank BRI Kcp Unit Inobonto dengan Desa Bantik berdasarkan hasil observasi penulis Jaraknya kurang lebih $7 \mathrm{~km}$, Sehingga jarak yang harus menggunakan kendaraan atau transportasi umum agar bisa ke bank menjadi dasar terhadap penelitian kali ini. Karena salah satu yang pengaruhi minat menabung merupakan lokasi ataupun tempat.

\section{METODE PENELITIAN}

Penelitian ini merupakan penelitian kuantitatif dan menjadikan masyarakat Desa Bantik yang menabung di Bank BRI sebagai populasi dalam penelitian ini. Karena tidak diketahui jumlah populasi masyarakat Desa Bantik yang menabung di bank BRI maka peneliti menggunakan rumus Hair untuk menentukan berapa ukuran sampel. Rumus Hair digunakan karena ukuran populasi yang belum diketahui dengan pasti. indikator dalam penelitian ini berjumlah 11, dan menggunakan 110 sampel responden.

Metode yang digunakan dalam pengambilan sampel merupakan metode nonprobability sampling (Suliyanto \& MM, 2017). Data primer diperoleh melalui sebaran kuesioner kepada seluruh responden sedangkan data sekunder diambil dari data literatur, jurnal maupun brouser yang berhubungan dengan penelitian ini. Adapun analisis data yang digunakan adalah uji kualitas data, uji asumsi klasik dan analisis regresi linier sederhana.

\section{HASIL DAN PEMBAHASAN}

Penulis melakukan analisis terhadap variable penalitian, Analisis ini berupa pengelompokan dan validitas dari varibabel yang diambil penulis.

\section{Tabel 1}

\section{Pengelompokan Berdasarkan Jarak Tempuh}

$\begin{array}{ccc}\text { Jarak } & \text { Jumlah } & \text { Presentase } \\ \leq \mathbf{3} \text { Km } & 0 & 0 \% \\ \mathbf{3 - 5} \mathbf{~ K m} & 0 & 0 \% \\ \mathbf{5 - 7} \mathbf{~ K m} & 0 & 0 \% \\ \geq 7 \text { Km } & 110 & 100 \% \\ \text { Total } & 110 & 100 \%\end{array}$

Sumber Data: Data Kuisioner Telah Diolah 2020

Berdasarkan tabel 1 di atas dapat dilihat untuk data responden berdasarkan jarak tempuh menunjukkan bahwa respondek dengan jarak $\leq 3 \mathrm{Km}$ sebanyak 0 orang $(0 \%)$, 
Kunuz: Journal of Islamic Banking and Finance Vol. 1, No. 1 (2021): 10-21 Website: http://ejournal.iain-manado.ac.id/index.php/kunuz

3-5 Km sebanyak 0 orang (0\%), 5-7 Km sebanyak 0 orang (0\%), $\geq 7 \mathrm{Km}$ sebanyak 110 orang $(100 \%)$ bermula jumlah keseluruhan sebanyak 110 responden $(100 \%)$.

\begin{tabular}{|c|c|c|c|}
\hline \multicolumn{4}{|c|}{$\begin{array}{c}\text { Tabel } 2 \\
\text { Hasil Uji Validitas Variabel X (Lokasi) }\end{array}$} \\
\hline Pernyatan & Person & $\begin{array}{c}(\mathrm{r}) \\
\text { Tahel }\end{array}$ & Keterangan \\
\hline 1 & 0,489 & 0,187 & Valid \\
\hline 2 & 0,522 & 0,187 & Valid \\
\hline 3 & 0,425 & 0.187 & Valid \\
\hline 4 & 0,485 & 0,187 & Valid \\
\hline 5 & 0,509 & 0,187 & Valid \\
\hline 6 & 0,501 & 0,187 & Valid \\
\hline 7 & 0,651 & 0,187 & Valid \\
\hline 8 & 0,642 & 0,187 & Valid \\
\hline 9 & 0,574 & 0,187 & Valid \\
\hline 10 & 0,624 & 0,187 & Valid \\
\hline 11 & 0,720 & 0,187 & Valid \\
\hline 12 & 0,671 & 0,187 & Valid \\
\hline
\end{tabular}

Sumber: Hasil Pengolahan Data oleh SPSS 24

Setelah dilakukannya uji validitas pada variabel X (Lokasi), tiap item dinyatakan valid sebab $r$ hitung $>r$ tabel $(0,187)$ sehingga semua seluruh pernyataan dapat dipergunakan dalam penelitian ini.

Tabel 3

Hasil Uji Validitas Variabel Y (Minat Menabung)

$\begin{array}{cccc}\text { Pernyatan } & \begin{array}{c}\text { Person } \\ \text { Correlation } \\ 0,476\end{array} & \begin{array}{c}\text { (r) } \\ \text { Tabel } \\ 0,187\end{array} & \text { Keterangan } \\ 1 & \text { Valid } \\ 2 & 0,542 & 0,187 & \text { Valid }\end{array}$


Kunuz: Journal of Islamic Banking and Finance Vol. 1, No. 1 (2021): 10-21 Website: http://ejournal.iain-manado.ac.id/index.php/kunuz

$\begin{array}{llll}3 & 0,709 & 0,187 & \text { Valid } \\ 4 & 0,697 & 0,187 & \text { Valid } \\ 5 & 0,580 & 0,187 & \text { Valid } \\ 6 & 0,634 & 0,187 & \text { Valid } \\ 7 & 0,534 & 0,187 & \text { Valid } \\ 8 & 0,510 & 0,187 & \text { Valid }\end{array}$

Sumber: Hasil Pengolahan Data oleh SPSS 24

Selanjutnya, untuk uji validitas variabel Y (Minat Menabung), seluruh item pula dinyatakan valid sebab nilai $r$ hitung $>\mathrm{r}$ tabel0,187

Tabel 4

Hasil Uji Reliabilitas Variabel X (Lokasi)

\section{Cronbach's $\quad \mathrm{N}$ of \\ Alpha Items}

$.833 \quad 13$

Sumber: Hasil Pengolahan Data Menggunakan SPSS 24

Setelah dilakukan pengujian, dapat diketahui nilai reliabel (Alpha Croanbach) untuk Variabel X (Lokasi) merupakan 0,833 dengan demikian bisa dikatakan hasil uji reliabilitas variabel $\mathrm{X}$ (Lokasi) $0,833>0,187$ sehingga Variabel $\mathrm{X}$ reliabel.

\section{Tabel 5}

Uji Reliabilitas Variabel Y Minat Menabung)

\begin{tabular}{|c|c|}
\hline \multicolumn{2}{|c|}{ Reliability Statistics } \\
\hline Cronbach's & $\mathrm{N}$ of \\
\hline Alpha & Item \\
\hline .730 & \\
\hline
\end{tabular}

Sumber: Hasil Pengolahan Data Menggunakan SPSS 24

Berikutnya, untuk Variabel Y (Minat Menabung), nilai reliabilitas (Alpha Croanbach) merupakan 0,730>0,187 sehingga maka disimpulkan bahwa Variabel Y reliabel. 
Tabel 6

Hasil Uji Normalitas

One-Sample Kolmogorov-Smirnov Test

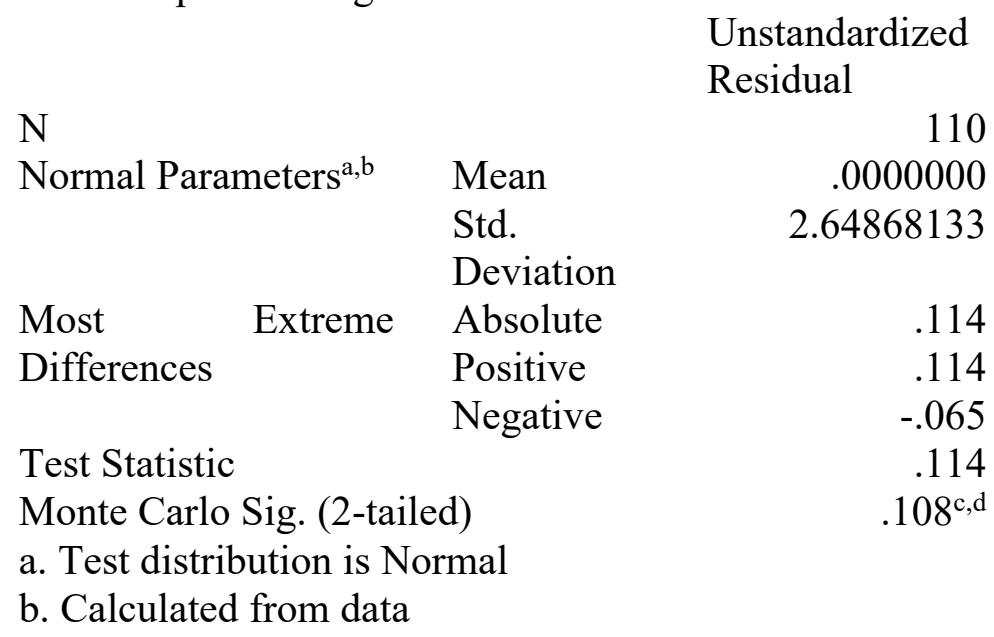

Sumber: Hasil Pengolahan Data Menggunakan SPSS 24

Diketahui nilai unstandardized residual merupakan 0.108. Dengan demikian dapat dikatakan hasil uji normalitas dengan menggunakan teknik kolmogorov-smimov dinyatakan berdistribusi normal karena mempunyai unstandardized residual > 0,05.

Uji korelasi bertujuan untuk mengidentifikasi tingkatan keeratan hubungan antar variabel yang dinyatakan dengan koefisien korelasi (r). Serta jenis hubungan antara variabel $\mathrm{X}$ dan $\mathrm{Y}$ dapat bersifat positif yaitu semakin tinggi variabel $\mathrm{X}$ maka akan meningkatkan variabel $\mathrm{Y}$ dan negative yaitu semakin tinggi variabel $\mathrm{X}$ maka akan menurunkan variabel Y.

Dasar dalam pengambilan keputusannya yakni apabila nilai signifikasi $<0,05$ maka berkorelasi, dan apabila nilai signifikasi $>0,05$ maka tidak berkorelasi.

Tabel 7

Tingkat Pedoman Derajat Hubungan

Nilai Pearson Correlation

$$
\begin{aligned}
& 0,00 \mathrm{~s} / \mathrm{d} 0,20 \\
& 0,21 \mathrm{~s} / \mathrm{d} 0,40 \\
& 0,41 \mathrm{~s} / \mathrm{d} 0,60 \\
& 0,61 \mathrm{~s} / \mathrm{d} 0,80 \\
& 0,81 \mathrm{~s} / \mathrm{d} 1,00
\end{aligned}
$$

Keterangan

Tidak ada Korelasi

Korelasi lemah

Korelasi Sedang

Korelasi Kuat

Korelasi Sempurna

Sumber: Hasil Pengolahan Data Menggunakan SPSS 24 


\begin{tabular}{llrr} 
& \multicolumn{1}{c}{$\begin{array}{c}\text { Tabel 8 } \\
\text { Uji Korelasi } \\
\text { Correlations }\end{array}$} & & \\
& & & \\
Lokasi & Lokasi & $\begin{array}{r}\text { Minat } \\
\text { Menabung }\end{array}$ \\
& Pearson & & $.618^{* *}$ \\
& Correlation & & .000 \\
Minat Menabung & Sig. (2-tailed) & & 110 \\
& N & 110 & 1 \\
& Pearson & $.618^{* *}$ & \\
& Correlation & & \\
& Sig. (2-tailed) & .000 & 110
\end{tabular}

Correlation is significant at the 0.01 level (2-tailed). Sumber: Hasil Pengolahan Data Menggunakan SPSS 24

Dengan melihat hasil tabel di atas dapat disimpulkan variabel Lokasi mempunyai korelasi dengan variabel Minat Menabung kerena nilai signifikasi $<0,05$. Dan memiliki derajat hubungan korelasi kuat karena memiliki nilai pearson correlation 0.618 .

\section{Analisis Regresi Linier Sederhana}

Pembuktian ini dimaksudkan agar menguji variansi sesuatu model regresi yang digunakan dalam menerangkan variabel bebas $(\mathrm{X})$ terhadap variabel terikat $(\mathrm{Y})$ dengan menguji kemaknaan dari koefisien regresi. Bersumber pada perhitungan dengan menggunakan bantuan SPSS 24 diperoleh hasil sebagai berikut.

Tabel 9

\section{Hasil Uji Regresi Linier Sederhana}

$\begin{array}{lcrcrr}\text { Model } & \begin{array}{c}\text { Coefficients }^{\mathbf{a}} \\ \text { Unstandardized } \\ \text { Coefficients }\end{array} & \begin{array}{c}\text { Standardiz } \\ \text { ed } \\ \text { Coefficient }\end{array} & \text { T } & \text { Sig. } \\ & & & & & \\ & \text { B } & \text { Std. Error } & \text { Beta } & & \\ 1 \text { (Constant) } & 2.614 & 3.362 & & .778 & .43 \\ & & & & & 9 \\ \text { Lokasi } & .500 & .061 & .618 & 8.167 & .00 \\ & & & & & 0\end{array}$

a. Dependent Variable: Minat Menabung 


\section{Sumber: Hasil Pengolahan Data Menggunakan SPSS 24} berikut.

Dari hasil tabel di atas, maka hasil yang diperoleh dimasukan dalam persamaan

$\mathrm{Y}=\mathrm{a}+\mathrm{Bx}$

Keterangan

$\mathrm{Y}=$ Variabel dependen (nilai yang diprediksikan)

$\mathrm{X}=$ Variabel independen

a $\quad=$ Konstanta (nilai $Y$ apabila $X=0$ )

$\mathrm{b} \quad=$ Koefisien regresi (nilai peningkaan ataupun penurunan)

Sehingga diperoleh persamaan fungsi regresi linier sederhana diatas merupakan seabagai berikut :

a. Nilai konstanta (a) sebesar 2.614 menampilkan bahwa variabel independen tetap, maka Minat Menabung adalah sebesar 2.614.

b. Nilai koefisien regresi X Lokasi bernilai positif 0,500 menyatakan bahwa jika Lokasi memuaskan, sebab nilai koefisien bertanda positif maka nilai Y Minat Menabung akan meningkat 0,500 .

\section{Uji t (Persial)}

Uji t digunakan untuk menguji signifikan pengaruh antara variabel X (Lokasi) Terhadap Variabel Y (Minat Menabung) apakah benar-benar berpengaruh. Pengujian ini dilakukan dengan metode membandingkan ttabel dengan thitung. Apabila thitung lebih besar dari pada ttabel dengan signifikan 0,05 (5\%), maka secara persial variabel bebas bepengaruh secara signifikan terhadap variabel terikat, begitu juga kebaliknya. Hipotesis yang akan digunakan dalam pengujian ini adalah:

Ho : Lokasi Bank BRI Kcp Unit Inobonto tidak mempengaruhi terhadap minat nasabah Desa Bantik untuk menabung.

Ha : Lokasi Bank BRI Kcp Unit Inobonto mempengaruhi terhadap minat nasabah Desa Bantik untuk menabung.

Dengan membandingkan nilai thitung dengan ttabel apabila thitung $>$ ttabel, maka Ha diterima dan Ho ditolak, apabila tabel $<$ thitung, maka Ho diterima dan Ha ditolak, dengan tingkat signifikasi 5\% $(\mathrm{a}=5 \%), \mathrm{n} 110, \mathrm{k}=1$

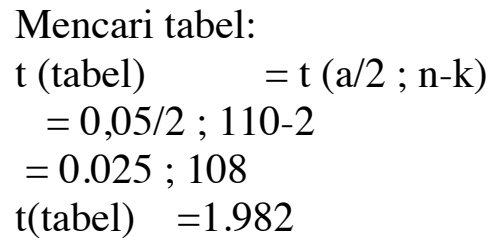

Hasil dalam penelitian inibisa dilihat hasil uji regresi linier sederhana, dapat diketahui bahwa thitung 8.167 > tabel 1.982 maka dapat disimpulkan bahwa Ha diterima dan Ho ditolak. 
Penelitian ini bertujuan untuk menguji dan menganalisis Pengaruh Lokasi Bank BRI Kantor Cabang Pembantu Unit Inobonto Terhadap Minat Nasabah Untuk Menabung (Studi Kasus Desa Bantik Kecamatan Bolaang Timur Kabupaten Bolaang Mongondow). Dari hasil analisis di atas, maka pembahasan tentang hasil penelitian sebagai berikut :

Apakah lokasi berpengaruh terhadap minat nasabah bank desa Bantik untuk menabung? Berdasarkan hasil penelitian diketahui bahwa variabel lokasi (X) berdasarkan uji t diperoleh dengan thitung $>$ ttabel yaitu 8,167 $>1,982$ yang berarti bahwa lokasi mempunyai pengaruh terhadap minat nasabah desa Bantik untuk menabung. Sedangkan nilai koefisien regresi sebesar 0.500 artinya lokasi berpengaruh sebesar 50.0\% terhadap keputusan nasabah desa Bantik untuk menabung.

Nilai koefisiem regresi positif disini dapat diartikan bahwa lokasi bank Bri yang strategi dan mudah dijangkau oleh sarana transportasi berpengaruh terhadap minat nasabah desa Bantik untuk menabung.

Pemilihan lokasi memiliki fungsi yang strategis karena bisa menentukan pencapaian tujuaan badan usaha dalam pengertian lain (Efrianto \& Suwitho, 2016; Lupiyoadi, 2010; Purnomo, 2016; Setiawan, 2016). Berdasarkan analisis diketahui bahwa lokasi menjadi salah satu faktor yang mempengaruhi untuk menabung di bank Bri kemudian pencapaian lokasi Bri dengan sarana dan prasarana untuk mencapai dimana Bank beroperasi misalnya akses yaitu lokasi dilalui atau mudah dijangkau sarana transportasi umum.

Lokasi juga dikarenakan oleh lingkungan misalnya dekat dengan perkantoran dan pasar, lokasi dapat dilihat jelas dari tepi jalan dan mempunyai tempat parkir yang luas dan aman. Sehingga nasabah menjadi muda untuk menabung di Bank Bri, jadi dari penjelasan tersebut secara taori dari hasil statistik menunjukkan bahwa lokasi berpengaruh terhadap minat nasabah desa Bantik untu menabung di bank Bri Kcp Unit Inobonto.

\section{KESIMPULAN}

Hasil penelitian menunjukan bahwa uji t (persial) dengan menyamakan antara nilai $t$ hitung dengan $t$ tabel dapat diketahui bahwa nilai thitung 8,167 $>$ ttabel 1,982 sehingga dapat disimpulkan bahwa Ha (Lokasi) Bank BRI Kcp Unit Inobonto berpengaruh terhadap minat menabung nasabah Desa Bantik Untuk Menabung.

Lokasi dalam perspektif Islam yaitu memilih tempat yang baik dan menghindari sebanyak mungkin seluruh segi-segi negatif dan mendapatkan lokasi dengan banyak faktor-faktor positif. Sehingga lokasi berpengaruh positif terhadap minat nasabah untuk menabung. 


\section{DAFTAR PUSTAKA}

Asmar, K. H. (2019). Pengaruh Pelayanan, Promosi, Lokasi, Dan Bagi Hasil Bank Terhadap Minat Nasabah Menabung Pada Pt. Bank Bri Syariah Kcp Sudirman Lubuk Pakam. Universitas Islam Negeri Sumatera Utara.

Astuti, T., \& Mustikawati, R. I. (2013). Pengaruh persepsi nasabah tentang tingkat suku bunga, promosi dan kualitas pelayanan terhadap minat menabung nasabah. Nominal: Barometer Riset Akuntansi Dan Manajemen, 2(1), 182-198.

Baja, S. (2012). Perencanaan Tata Guna Lahan dalam Pengembangan Wilayah. Penerbit Andi.

Daroin, A. D., \& Ningtias, A. P. (2020). Permasalahan dan Solusi Pengembangan Perbankan Syariah di Kota Madiun. EQUILIBRIUM: Jurnal Ilmiah Ekonomi Dan Pembelajarannya, 8(2), 140-154.

Efrianto, A., \& Suwitho, S. (2016). Pengaruh Harga, Lokasi, Promosi Dan Layanan Terhadap Keputusan Menginap Di Hotel The Alana Surabaya. Jurnal Ilmu Dan Riset Manajemen (JIRM), 5(9).

Hadiwijaya, D. (2020). Perilaku Nasabah Berdasarkan Kinerja Customer Relationship Management Sebagai Dampak Dari Kompetensi Sumber Daya Manusia, Mutu Pelayanan Bank Dan Teknologi Perbankan Terhadap Kepuasan Nasabah (Studi pada Nasabah Bank Kota Tangerang). JMB: Jurnal Manajemen Dan Bisnis, 9(1), $10-20$.

Hasibuan, A. A. (2020). Pengaruh pengetahuan, lokasi dan religiusitas santri terhadap minat menabung di bank syariah (studi kasus santri pondok pesantren Darul Falah Langga Payung). IAIN Padangsidimpuan.

Homsatun. (2017). Pengaruh Lokasi, Pelayanan dan Kualitas Produk terhadap Minat Nasabah untuk Menabung pada PT Bank Muamalat Cabang Kendari. IAIN KENDARI.

Kasmir. (2004). Dasar-Dasar Perbankan. PT Grafindo Persada.

Kasmir. (2017). Manajemen Perbankan. Rajawali Pers.

Kotler, P., \& Keller, K. L. (2011). Manajemen Pemasaran (Terjemahan). Erlangga.

Lupiyoadi. (2010). Manajemen Pemasaran. PT. Raja Grafindo Persada.

Pandiangan, H. J. (2018). Sistem Perbankan dalam Negara Kesejahteraan di Indonesia. To-Ra, 4(2), 52-71.

Purnomo, E. (2016). Pengaruh Harga, Kualitas Produk dan Lokasi Terhadap Minat Beli Konsumen Dalam Membeli Beras Lokal (Studi Kasus Desa Rambah Utama). Universitas Pasir Pengaraian.

Reshita, R. (2015). Pengaruh Promosi, Lokasi, dan Kualitas Pelayanan Terhadap Minat Menabung Nasabah Di Bank BNI Sidoarjo. STIE Perbanas Surabaya.

Setiawan, R. I. (2016). Pengembangan sumber daya manusia di bidang pariwisata: perspektif potensi wisata daerah berkembang. Jurnal Penelitian Manajemen

Pengaruh Lokasi Bank Rakyat Indonesia Kantor Cabang Pembantu Unit Inobonto Terhadap Minat Nasabah Untuk Menabung Olive Marina Paputungan, Syarifuddin, Ramli Semmawi 
Kunuz: Journal of Islamic Banking and Finance Vol. 1, No. 1 (2021): 10-21 Website: http://ejournal.iain-manado.ac.id/index.php/kunuz

Terapan (PENATARAN), 1(1), 23-35.

Simatupang, H. B. (2019). Peranan perbankan dalam meningkatkan perekonomian indonesia. JRAM (Jurnal Riset Akuntansi Multiparadigma), 6(2), 136-146.

Suliyanto, S. E., \& MM, S. (2017). Metode Penelitian Kuantitatif. Universitas Peradaban.

Wiwoho, J. (2014). Peran lembaga keuangan bank dan lembaga keuangan bukan bank dalam memberikan Distribusi keadilan bagi masyarakat. Masalah-Masalah Hukum, 43(1), 87-97. 